\title{
Exploring Hindrances in the Implementation of Continuous Assessment of EFL Teachers: A Case in AbbiyAddi and Adwa Teacher Educational Colleges
}

\author{
Tegegne Mekuria Asfaw (M.ED in TEFL)
}

Department of English Language and Literature, Adigrate University, P.o.Box 50, Adigrat, Tigray, Ethiopia

\begin{abstract}
The intention of this research was to explore the hindrances of implementing students' continuous assessment and recommends possible solutions to the hindrances. Four basic questions were raised to achieve the objectives of the study. To respond these basic research questions, descriptive survey research method was used. Instructors, college deans and students were participants of the study. The colleges and participants were selected by stratified random sampling method. The chief results of this study include especially frail document handling and poor record keeping of learners' continuous assessment achievement. Numerous assessment techniques were used improperly. The research also found that large class sizes shortage of college infrastructure, lack of manuals, weak follow up support and feedback system on the implementation of continuous assessment, lack of positive attitude and playground in the colleges were the major hindrances of continuous assessment. Intended for supplementary improvement, continuous on the job training, sufficient and updated manuals, support and immediate feedback on the learners' continuous assessment implementation, fulfillment of facilities and materials and also adequate playground were suggested as potential solutions to the proper implementation of continuous assessment.
\end{abstract}

Keywords: EFL, continuous assessment, implementation, improvement, Assessment

\section{Introduction}

\subsection{Background of the Study}

Continuous assessment is a classroom strategy implemented by teachers to ascertain the knowledge, understanding, and skills attained by pupils. Teachers administer assessments in a variety of ways over time to allow them to observe multiple tasks and to collect information about what pupils know, understand, and can do. These assessments are curriculum-based tasks previously taught in class. Continuous assessment occurs frequently during the college year and is part of regular instructor-pupil interactions. Pupils receive feedback from instructors based on their performance that allows them to focus on topics they have not yet mastered. Instructors learn which students need review and remediation and which pupils are ready to move on to more complex work. Thus, the results of the assessments help to ensure that all pupils make learning progress throughout the school cycle thereby increasing their academic achievement.

Assessing in education is a hindrance for students and teaching staff alike. Students frequently find themselves forced to leapfrog across what can seem like countless assessment hurdles in the course of their training. At the same time, teachers (lecturers, tutors and practice teachers) need to ensure that assessment tasks are as effective and fair as possible. It has been argued that the exploration process may either facilitate or inhibit transfer of learning, depending on its nature, systems and procedures (Cree et al. 1998 cited in Gemechu 2013).

Assessment is of central importance to students' learning (Brown et al. 1997). It sets parameters on what students think of as important, how they spend their time and how they see themselves as learners and even as human beings.
Brown et al. (1997) argue that 'If you want to change student learning then change the methods of assessment'. The implication being that it is primarily concerned with collaboration rather than inspection (Brockbank and McGill, 1998). In the real world of assessment in higher and professional education, the experience of being assessed may be very different from this.

Exploration consists, essentially, of taking a sample of what students do, making inferences and estimating the worth of their actions. The behaviors sampled may be specific to a course or they may be more general. They may be related to explicit or implicit criteria. The sampling may be undertaken by the students themselves, their peers, their tutors or employers with whom they are working. On the basis of the sample that is taken, inferences are made about a person's achievements, potential, intelligence, aptitudes, attitudes, motivations and, perhaps, personality and an estimate of worth in the form of grades, marks or recommendations is made (Brown et al. 1997).

Therefore, one can say or easily understand that the significance of using continuous assessment in teaching and learning process to improve the quality of education is unquestionable. Supporting this idea, Brown and Knight (1994) and Gronlund (1981) pointed out that evaluating pupils learning on a continuous basis by focusing on basic instructional objectives plays important role in maintaining the quality of education.

These days many countries such as Spain, Australia, England and others are applying continuous assessment partly or wholly in their educational system (Heaton, 1990 cited in Gemechu, 2014). On top of this, Nikko (1995) states that in many countries educators are expressing their interest toward continuous assessments into two different ways Their interests appear to arise from related, but different 


\section{International Journal of Science and Research (IJSR) \\ ISSN (Online): 2319-7064}

Index Copernicus Value (2015): 78.96 | Impact Factor (2015): 6.391

educational concerns. First educator recognizes that good instruction requires information about the instruction requires information about the student progress. The second reason for educators' interest in continuous assessment is to become fair to the students. Assessment is, then, the process of sampling students' work and drawing inferences from that sample. Beyond this broad description, a number of specific questions emerge. How is the sample to be chosen? By whom? When should the Middle Eastern \& African Journal of Educational Research, Issue 7 Year 2014,76 sample be taken? What about students' work that is not included in the sample? How are the inferences to be made? Again by whom? In the Ethiopian context, the New Education and Training Policy gave emphasis on the use of continuous assessment. The aim of the new policy of continuous assessment in Ethiopian context is to bring a paradigm shift from old aged traditional system of assessment that is a judgmental role in its orientation to developmental role. Hence, the new education and training policy of the country calls for the use of continuous assessment to realize the educational objectives. Despite the importance of the proper implementation of continuous assessment, it might not go beyond lip service. Therefore, exploring the hindrance of implementation of continuous assessment is found to be actual fundamental.

\subsection{Statement of the Problem}

The teaching and learning process desires uninterrupted transcribe to accomplish its objectives. The continuous assessment process is much more than an examination of pupil achievement. Continuous assessment is also a powerful diagnostic tool that enables pupils to understand the areas in which they are having difficulty and to concentrate their efforts in those areas. Continuous assessment also allows teachers to monitor the impact of their lessons on pupil understanding.

consequently continuous assessment is indispensable to check the realization of instructional objectives. Conventional assessment method mainly focuses on testing which encourages superficial learning, but did not assess the wider skills of pupils. Hence, continuous assessment should be essential to measure learners' performance in a holistic manner. There might be changes to better or the worse. This creates a researcher a curiosity to investigate the status of continuous assessment of EFL teachers in central Zone of Tigray Regional state with Special Attention to AbbiyAddi and Adwa teacher educational college and preparatory schools.

\subsection{Research Questions}

To achieve the objective of the study, the research attempted to address the following questions:

1) Is a consistent, timely and descriptive feedback provision practiced within the classes by Teacher- educators and student-teachers of the college?

2) How often do the teacher-educators and student-teachers implement the techniques of Continuous assessment within the classes?

3) What are the challenges ofcontinuous assessment within classes?
4) Does the grading frame of reference-work match with the principles of the continuousassessment?

\subsection{Objective of the study}

\subsubsection{General objective}

The main purpose of this study is to find out the hindrances associated with the implementation of continuous assessment as perceived by teacher education college in Tigray regional state.

\subsubsection{Specific objectives}

The specific objectives of this study are intended to:

- Distinguish the major types of continuous assessment techniques practiced in Tigray regional state TeacherEducation College

- Investigate how often continuous assessment techniques is practiced in Tigray regional state

- Teacher Education College.

- Explore hindrances of continuous assessment implementation in the Tigray regional state Teacher education college

- Recommend the proposed solution to the stakeholders (students, teachers, middle and top management bodies of the college.)

\subsection{Significance of the study}

The findings of this research might have the following payback:

- Given that the major participants of the study was teachers of Tigray regional state Teacher education college, the research should benefit them to examine their practices of continuous assessment.

- It lends a hand students of the college to get the advantages they should get from continuous assessment.

- It should do good to the administrative bodies of the college to examine the major obstacles of implementing continuous assessment in the College and re-plan for effectiveness of continuous assessment.

- Finally, it offers valuable information for other similar colleges to evaluate their assessment practices and implementation.

\subsection{Delimitation of the study}

The problem might be on a national scale which needs an extensive exploration Also, it would have been good if the research would include the various teacher education colleges in the country in order to have more consistent information. However, to make the study manageable with the available time and with the limited budget, the study was encircled to Tigray regional state Teacher education college and preparatory schools.

\subsection{Limitations of the study}

The research would have been more reliable if observation and document analysis are used. So, this was the major limitation of the study. 


\section{Review of Related Literature}

\subsection{Definition and Principles of Continuous Assessment}

\subsubsection{Definition of Continuous Assessment(CA)}

$\mathrm{CA}$ is a formative mode of assessment that used multiple ways and format. It combines the scores obtained from paper pencil, assignment projects, discussion and presentations, oral paper penal, observation, etc. this and suit a lot of definition have been given by many scholars /researchers, educators, psychomotricions, etc.

However, it may not be feasible, need impossible to mention all here, and rather those related to the domain of the study i.e. continuous assessment of learners' overage progress are given emphasis.

Continuous assessment is a process of collection and interpretation of information to make decisions about learners based on what they know and can demonstrate as a result of classroom instruction (copper, 1996)

Thus, from the above definitions continuous assessment is a process that is used in collecting information about students' performance with regard to all learning domains made throughout the teaching learning process

From those definitions we can dive out the following main points.

- CA is a tool to collect information about learners

- It involves interpretation of information to have objective ground to make decisions with regard to learners rearming status.

The change in the assessment policy was introduced in the South Africa schools in 2001 by the former Minister of Education, Prof. Kader Asmal. Alausa (2003:2) ascribed one advantage of $\mathrm{CA}$ to the fact that it places teachers at the center of all performance-assessment activities and that it encourages more teacher participation in the overall assessment or grading of learners. He further states that this new assessment model is used to determine the learner's achievement during the course of the grade or level, and to provide information that is used to support a learner's development and enable improvements to be made in the learning and teaching process. Although the change in the assessment policy was intended to improve the quality of teaching, learning and assessment, it also introduced schools to the challenges associated with the implementation of educational change. The argument presented in this study is simply that every change produces new information and concepts which create challenges. The change in assessment policy calls for a realignment of existing values, practices and outcomes (Morrison, 1998:11). Alausa (2003:3) identified some of the problems working against the proper implementation of $\mathrm{CA}$ which calls for the realignment of values, practices and outcomes in schools. Some of the challenges that are associated with educators include a lack of skills in test construction and test administration, attitudes towards $\mathrm{CA}$, and record keeping. For CA implementation to succeed, Alausa (2003:3) argues that teachers need to give more tests and that will result in more marking for the teachers. They are expected to constantly observe learners to see if they are progressing towards the set outcomes. All these could mean more work for the teachers, greater demands on their time, and increased responsibility.

\subsubsection{Principles of Continuous Assessment}

$\mathrm{CA}$ is an ongoing process in teaching and learning but not episodic. This process like other processes is most effective when based on sound operational principles. These principles provide to the tutor a framework within which the process of assessment is practiced. They include:

Determining and clarifying what to be assessed. There is need for a tutor to determine an assessment device after defining the purpose (s) of assessment. Assessment works best when the programmer seeks to improve have clear, explicitly stated purposes. As a tutor critically identify the education values you intend to assess on who in terms of what and how alongside where.

The assessment techniques strategies or tools should be selected in terms of the purpose to be served

Each assessment technique tool is appropriate in one instance and in appropriate to another, therefore as a tutor consider the appropriateness of the technique or tool for the intended purpose prior to its selection.

Comprehensive assessment requires a variety of assessment techniques for triangulation purposes

No single assessment tool or technique is good or adequate enough for appraising learner progress towards all the important out comes of instruction. Assessment requires attention to outcomes but also equally to experiences that lead to those out comes therefore assessment is most effective when it reflects on understanding of learning as multi-dimensional, integrated and revealed in performance over time

Proper use of assessment techniques, tools requires awareness of their limitations strengths and appropriateness

All measuring instruments tools are subject to one or more types of errors as tutors you need to use proper and accurate assessment results aware of such instrument errors; use the most appropriate tool for a specific learning out come

\section{Assessment is a means to an end but not an end in itself}

The use of assessment techniques, tools means that some useful purpose will be served and the tutor will be clearly aware of the purpose. The type of decisions made should be identified before assessment procedures are selected.

\section{Good assessment practices promote ethical academic conduct}

Ethical academic conduct is both a staff and students' responsibility. Good assessment design can both educate students about appropriate academic conduct and minimize academic misconduct. Assessment practice allows students to receive timely feedback on their learning. High quality feedback is clear and constructive, an enables students to

\section{Volume 6 Issue 7, July 2017 www.ijsr.net}




\section{International Journal of Science and Research (IJSR) \\ ISSN (Online): 2319-7064}

Index Copernicus Value (2015): 78.96 | Impact Factor (2015): 6.391

make sensible judgments about modifying aspects of their academic performance in order to meet the objectives of the course. Such feedback should enable students to understand their level of development of the required skills, their mastery of understanding embedded in the assessment activity and how their performance in each domain could be improved in subsequent learning activities.

\section{Assessment methods should be valid reliable and consistent}

Tutors should make effort to ensure that assessment methods are valid and reliable, recognizing that professional judgment is a significant and reasonable element in the indicators of achievement. It is also reasonable that such judgment is regularly subjected to peer review and discussion.

Assessment fosters wider improvement when representatives from across the educational community are involved.

Teacher trainee learning is a-campus-wide responsibility, and assessment is a way of enacting that responsibility. As a tutor you should involve individuals from beyond the campus whose experience can enrich the sense of appropriate aims and standards for learning. Therefore treat assessment as a collaborative activity by all parties with a stake in its improvement.

\subsubsection{Language Teaching and Assessment}

Language teaching and assessment are so closely interrelated that it may be difficult to view them separately. Language assessment is an integral part of language teaching.

That may be why; many scholars confirm that it is difficult to achieve the goals of language teaching without the practice of language assessment (Taylor, 2006; IrvineNiakaris, 1997; Hughes, 1989; Heaton, 1988). "Without assessment it will be impossible to tell whether any learning has taken place" (NIED of Namibia, 1999:5).

Assessment contributes a lot for setting goals, planning, and practices of language teaching and learning. DES/WO (1988), as cited in Lambert and Lines (2000:109), states:

Promoting children's learning is a principal aim of schools. Assessment lies at the

heart of this process. It can provide a framework in which educational objectives

may be set, and pupils' progress charted and expressed. It can yield a basis

for planning the next educational steps in response to children's needs... it should be

an integral part of the educational process, continually providing both

'feedback' and 'feed forward'. It therefore needs to be incorporated systematically

into teaching strategies and practices at all levels.

Tests and exams give a 'snapshot of the learner' that can be used for the purpose of judgment. This approach of assessment may have given the way to an alternative type of assessment. Puhl (1997:1) asserts this by saying: "One consequence of these influences [affecting education and how we assess it]... is the move away from the heavy use of conventional, more judgmental approaches to assessment toward alternative, more inclusive means of determining what learners know and can do". Hence, the need for using assessment to improve the teaching learning process paved the way for developing another type of assessment -continuous assessment. Plessis et al. (2003:8) say:

When more of the school age children are given a chance to attend school

(as is happening these days in many countries), the range of abilities of the learners

in a classroom is greater. In the past, tests were used to find the best students and pass

them on to the next grade or level. Now, in many countries, the emphasis is on helping

all learners succeed in school.

It is important to know the meaning and purposes of assessment in order to understand the various characteristics and practices of continuous assessment. Hence, the meaning and purposes of assessment are discussed in some details below.

\subsection{Purpose of Classroom Assessment}

Different scholars have given definitions and purpose for assessment. For example, Erwin (1991: 45) defines assessment as:

A systematic basis for making inferences about the learning and development of students...

The process of defining, selecting, designing, collecting, analyzing, interpreting and using

information to increase students' learning and development.

Assessment is a way of knowing the progress of students in their learning. This can be done by gathering valuable data about students, giving meaning to the data, and using them to improve students' learning. Plessis et al. (2003:6) give a more comprehensive definition of assessment.

\section{Research Methodology}

\subsection{Research Design}

In this research, a descriptive survey research design involving both qualitative and quantitative techniques was employed.

\subsection{Sampling Techniques and Sampling size}

The study population included 22 EFL instructors and 60 first year students 40 second year English students of AbbiyAddi and Adwa Colleges of Teachers' Education in 2015/16 academic year with equal proportion. AbbiyiAddi and Adwa College of Teachers' Education, which is one of the colleges of teachers' education in Tigray Regional State, was selected as the site of the study based on comprehensive sampling procedure. These college have been currently running a three-year-cluster modality of diploma program. English courses have been taught to students who have successfully completed grade 10 and 12 and met the minimum requirements to join the three-year training.

\section{Volume 6 Issue 7, July 2017 www.ijsr.net}




\section{International Journal of Science and Research (IJSR) \\ ISSN (Online): 2319-7064}

Index Copernicus Value (2015): 78.96 | Impact Factor (2015): 6.391

\subsection{Instruments Used for the Study}

Questionnaire, interview, observation and document analysis will be used for the study. Questionnaires were developed for both teachers and students. Interview was also developed for the dean and vice academic dean to supplement the data was gather using questionnaire. The instruments were prepared based on the objectives of the study and the literature.

\subsubsection{Teachers' Questionnaires}

Teachers' questionnaires were closed-ended and open-ended questionnaires. The closed-ended questionnaire have three parts. The first one was prepared to find out teachers' understanding of the principles and purposes of continuous assessment. In this part, 15 items adapted from Hedge (2000) were used. The response modes of the items were'strongly agree', 'agree', 'uncertain', 'disagree' and 'strongly disagree'.

The second part was developed to see teachers' primary use of Continuous assessment results and way of giving feedback to students' Continuous assessment activities. Seven items were prepared for this part. The response modes used were checklists (yes/no) and 5-point Likert scale (always (5) to never (1)). The items were adapted from Nitko (2005 cited in SileshDemissa) and the available literature.

The last part was developed to find out teachers' implementation of Continuous assessment devices. Eleven 5-point Likert -scale items were prepared. These items are adopted from the American Institutes for Research (2003). The scale ranges from always (5) to never (1).

The open-ended questionnaire is prepared to investigate mainly the problems that teachers face in their implementation of Continuous assessment. The teachers were also asked to suggest solutions for the successful implementation of Continuous assessment. Moreover, some items that were intended to investigate teachers' participation in any Continuous assessment relate training /workshop and the contents of the training and its impacts on them are included in this section of the questionnaire. Interview is also conducted as a follow-up tool.

\subsubsection{Students' Questionnaires}

These were closed-ended and open-ended questionnaires. The closed-ended questionnaire have two parts. The first one was developed to investigate teachers' implementation of the various aspects of continuous assessments perceived by students and the problems students face in their teachers' practices of Continuous assessment. The questionnaire consisted of 15 items that were adapted from Apple and Shimo (2004), and the available literature. It will have a 5point scale whose response mode was 'strongly agree', 'agree', 'uncertain', 'disagree' and 'strongly disagree'.

The second part is prepared to see instructors' implementation of Continuous assessment devices as perceived by students. Eleven 5-point scale items, which ranges from always (5) to never (1), are prepared. In the open-ended questionnaire, the students are asked what strengths and weaknesses. They observedin their teachers' practices of Continuous assessment. Interview I also developed and conducted to support the data obtained from the questionnaire.

\subsubsection{Dean and Vice Dean Interview}

For deans' interview, six items adapted from the available literature were used. The items were prepared to support the data obtained from the questionnaire. They mainly focused on the problems of teachers face and the role of deans' in their implementation of Continuous assessment.

These were developing to support the data collected through the questionnaire. The focus of the items was on the hindrance of instructors' and role of deans onthe implementation of Continuous assessment. Two deans and two deans were involved in the interview. They were selected based on comprehensive sampling technique. For both deans and vice deans, the interview was recorded for analysis.

\subsubsection{Observation}

Classroom observation as a substantiating tool was also used because observational data helped the researchers to see directly what people did without having to rely on what they said they do (Dornyei, 2007).

To make the observation, a structured observation checklist was prepared but each event of the process was described qualitatively. Six teachers were observed in order to check whether what they responded to the questionnaires and interview questions match what they actually do in the class.

They were selected on the basis of their relative experience in teaching English as a foreign language. The observation focused on the class size, frequency of feedback provision and continuous assessment (CA) plans. Each teacher was observed for three rounds, each round for 50 minutes.

\subsubsection{Document analysis}

Document analysis was carried out to examine the rate of English teachers' continuous assessment from the two colleges. To see the trends of teachers' continuous assessment attrition, the documents from the Academics dean and department heads are consulted. For this purpose documents from 2010-2015 were analyzed.

\subsection{Procedure of Data Collection}

It was shown in the above; data for the research was collected through questionnaire and interview and also observation. Before administrating the questionnaires to teachers and students, a short explanation was given on the purpose of the, questionnaires. Teachers' questionnaires were collected one day after the day they were administered. In the interview, the consent of the interviewees was asked and approved before it was conducted.

\subsection{Data Analysis}

All the data collected were organized and analyzed in a way appropriate to answer the statement of the problem. The data was organized based on teachers' usage of continuous 


\section{International Journal of Science and Research (IJSR) \\ ISSN (Online): 2319-7064}

Index Copernicus Value (2015): 78.96 | Impact Factor (2015): 6.391

assessment, teachers' implementation of , and teachers' and students' problems and check and balance of deans in the implementation of continuous assessment.

Both quantitative and qualitative data analysis methods were used in the research. The data was collected through closedended questionnaire were analyzed quantitatively. To determine teachers' primary use of continuous assessment and their implementation of continuous assessment devices, mean and standard deviation were calculated. The expected (ideal) mean was three. Zero standard deviation means there is no variation among teachers in using that particular point whereas the highest variation was two. Therefore, if the calculated mean of a particular point is above the ideal mean, it can be said that the teachers implemented that particular point in their continuous assessment process. Percentage was used to find out teachers' view of continuous assessment and students' view of their teachers' practices of continuous assessment. Finally, the data collected using open-ended questionnaire and interview were analyzed qualitatively for both teachers and students.

\section{Presentation, Analysis and Interpretation of Data}

\subsection{Introduction}

In this chapter, findings of this study are presented based on the research questions. These findings are based on 33 questionnaires from the instructors, 15 questionnaires from the students and 6 interviews and 11 observation checklist filled by deans of the college.

Table 2: Review of Teachers' Responses to their crucial Use of CA

\begin{tabular}{|c|c|c|c|c|c|c|c|c|c|c|}
\hline \multirow[t]{2}{*}{$\mathrm{NO}$} & \multirow{2}{*}{$\begin{array}{c}\text { Techniques of } \\
\text { Continuous } \\
\text { Assessment }\end{array}$} & \multicolumn{2}{|c|}{\begin{tabular}{|c|} 
Positive \\
$(5+4)$
\end{tabular}} & \multirow[t]{2}{*}{$\mathrm{F}$} & \multirow{2}{*}{$\begin{array}{c}\text { Percentages } \\
(\%)\end{array}$} & \multicolumn{3}{|c|}{\begin{tabular}{|l} 
Negative \\
$(3+2+1)$ \\
\end{tabular}} & \multirow[t]{2}{*}{$\mathrm{F}$} & \multirow{2}{*}{$\begin{array}{l}\text { Percent } \\
\text { ages } \\
(\%)\end{array}$} \\
\hline & & 5 & 4 & & & 3 & 2 & 1 & & \\
\hline 1 & Plan instruction & & 2 & 9 & 40.9 & 10 & 8 & 2 & 20 & 90.9 \\
\hline 2 & \begin{tabular}{|c|} 
Adjust your \\
teaching during the \\
lesson
\end{tabular} & 3 & 5 & 7 & 8 & 10 & 5 & - & 15 & 68.2 \\
\hline 3 & Re-teach a lesson & - & 6 & 6 & 27.3 & 11 & 3 & - & 14 & 63.6 \\
\hline 4 & $\begin{array}{c}\text { Monitor students' } \\
\text { learning }\end{array}$ & 3 & 3 & 6 & 27.3 & 12 & 4 & - & 16 & 72.7 \\
\hline 5 & $\begin{array}{c}\text { Give feedback for } \\
\text { Improvement }\end{array}$ & 3 & 5 & 8 & 36.4 & 10 & 4 & - & 14 & 63.6 \\
\hline 6 & $\begin{array}{c}\text { Evaluate students' } \\
\text { application of their } \\
\text { knowledge to real } \\
\text { world situations }\end{array}$ & - & 5 & 5 & 22.7 & 12 & 3 & 2 & 17 & 77.3 \\
\hline 7 & $\begin{array}{c}\text { Judge students' } \\
\text { language } \\
\text { achievement }\end{array}$ & 12 & 6 & 18 & 81.8 & 4 & - & - & 4 & 18.2 \\
\hline
\end{tabular}

As can be seen from Table 2, $90.9 \%$ the EFL instructors reported that they used CA results primarily to judge students' language achievement and give feedback for improvement but $40.9 \%$ with little frequency among them. They also used CA results to adjust their teaching during the lesson about $68.2 \%$ of respondents assured in a significant way though not as frequently as the former two decisions.

Table 3: Review of Teachers' Response to Their performs of CA tools

\begin{tabular}{|c|c|c|c|c|c|c|c|c|c|c|}
\hline \multirow[t]{2}{*}{$\mathrm{NO}$} & \multirow{2}{*}{$\begin{array}{c}\text { Techniques of Continuous } \\
\text { Assessment }\end{array}$} & \multicolumn{2}{|c|}{ Positive $(5+4)$} & \multirow[t]{2}{*}{$\mathrm{F}$} & \multirow{2}{*}{$\begin{array}{c}\text { Percentages } \\
(\%)\end{array}$} & \multicolumn{3}{|c|}{ Negative $(3+2+1)$} & \multirow[t]{2}{*}{$\mathrm{F}$} & \multirow{2}{*}{$\begin{array}{l}\text { Percent } \\
\text { ages }(\%\end{array}$} \\
\hline & & 5 & 4 & & & 3 & 2 & 1 & & \\
\hline 1 & Attendance & 25 & 30 & 55 & 56.1 & 37 & 5 & 1 & 43 & 43.9 \\
\hline 2 & Classroom participation & 20 & 32 & 52 & 53.1 & 40 & 6 & - & 46 & 46.9 \\
\hline 3 & Self_assessment & 15 & 20 & 31 & 31.6 & 50 & 12 & 5 & 67 & 68.4 \\
\hline 4 & Paper-pencil made exam & 70 & 20 & 90 & 91.8 & 4 & 3 & 1 & 8 & 8.1 \\
\hline 5 & Oral presentation & 45 & 36 & 81 & 82.7 & 13 & 3 & 1 & 17 & 17.3 \\
\hline 6 & Extended essay & 25 & 30 & 55 & 56.1 & 31 & 8 & 4 & 43 & 43.9 \\
\hline 7 & Group works & 22 & 26 & 48 & 49 & 40 & 7 & 3 & 50 & 51 \\
\hline 8 & Individual work & 60 & 25 & 85 & 86.7 & 10 & 2 & 1 & 13 & 13.3 \\
\hline 9 & Observation & 3 & 5 & 8 & 8.1 & 56 & 25 & 9 & 90 & 91.9 \\
\hline 10 & Portfolios & 4 & 8 & 10 & 10.2 & 57 & 27 & 4 & 88 & 89.8 \\
\hline 11 & peer assessment & - & - & & & 3 & 45 & 55 & 98 & 100 \\
\hline
\end{tabular}

As shown above in the table 3 all the eleven types and techniques of continuous assessment, only oral presentation (81, 82.7), classroom participation $(52,53.1)$, attendance $(55,56.1)$, Extended essay $(55,56.1 \%)$, Individual works $(85,86.7 \%)$ and Paper pencil made exam $(90,91.8 \%)$ were identified as a positive and the major types, techniques and frequently used type of continuous assessment techniques practiced in AbbyiAddi and Adwa teachers education college in 2015/16 academic year. To sum up, the majority of the respondents have agreed that in assessing the pupils' the presence of powerful intervening variables in the instructional process, severely hampered the efforts of the teachers to institute continuous assessment approaches in the sample secondary schools. Factors such as overcrowded classes and restricted facilities, equipment, lack of time, and student related variables often minimize the viability of continuous assessment in physical education. Moreover, such variables listed later often challenges to implement continuous assessment in EFL were also identified in table 8 as a major barriers: student negative attitude towards EFL subject, lack of sufficient time, large class size, and shortage of instructional materials. 


\section{International Journal of Science and Research (IJSR) \\ ISSN (Online): 2319-7064}

Index Copernicus Value (2015): 78.96 | Impact Factor (2015): 6.391

Table 4: Review of students' Responses to Their outlook of CA

\begin{tabular}{|c|c|c|c|c|c|c|c|c|c|c|c|}
\hline \multirow{3}{*}{$\begin{array}{l}\text { Ser } \\
\text { No }\end{array}$} & \multirow[t]{3}{*}{ Questionnaire Items } & \multicolumn{2}{|c|}{ Agreement } & \multirow{3}{*}{$\begin{array}{c}\text { Total } \\
\mathrm{f}\end{array}$} & \multicolumn{3}{|c|}{ Uncertain } & \multicolumn{2}{|c|}{ Disagreement } & \multicolumn{2}{|c|}{ Total } \\
\hline & & \begin{tabular}{|c|} 
Strongly \\
Agree
\end{tabular} & Agree & & \multirow[b]{2}{*}{$\%$} & \multirow[b]{2}{*}{$\mathrm{f}$} & \multirow[b]{2}{*}{$\%$} & Disagree & $\begin{array}{l}\text { Strongly } \\
\text { Disagree }\end{array}$ & \multirow[t]{2}{*}{$\mathrm{F}$} & \multirow[t]{2}{*}{$\%$} \\
\hline & & $\mathrm{f}$ & $\mathrm{F}$ & & & & & $\mathrm{f}$ & $\mathrm{F}$ & & \\
\hline 1 & In CA I usually make self-assessment on my own work & 10 & 9 & 19 & 19.4 & - & - & 34 & 35 & 69 & 70.4 \\
\hline 2 & $\begin{array}{c}\text { My teachers and peers give me feedback on my } \\
\text { progress in CA }\end{array}$ & 20 & 22 & 42 & 42.8 & & & 26 & 30 & 56 & 57.1 \\
\hline 3 & $\begin{array}{c}\text { My teachers' assessment in CA focuses on what I do } \\
\text { rather than on how I do }\end{array}$ & 10 & 14 & 24 & 22.7 & - & - & 44 & 30 & 74 & 77.27 \\
\hline 4 & $\begin{array}{c}\text { I feel that my teachers use CA to label or grade us, not } \\
\text { to see our language learning progress }\end{array}$ & 8 & 12 & 20 & 20.4 & 3 & 3.1 & 27 & 48 & 75 & \begin{tabular}{|l}
76.5 \\
\end{tabular} \\
\hline 5 & $\begin{array}{c}\text { CA helped me in understanding what I should improve } \\
\text { next }\end{array}$ & 13 & 26 & 39 & 39.8 & 2 & 9.1 & 35 & 22 & 57 & 58.2 \\
\hline 6 & $\begin{array}{l}\text { I feel that my teachers and I (we) negotiate how our } \\
\text { assignments are going to be scored or graded }\end{array}$ & 12 & 19 & 31 & 31.6 & 3 & 13.6 & 44 & 20 & 64 & 65.3 \\
\hline 7 & $\begin{array}{l}\text { I believe that the grades my works are awarded in CA } \\
\text { are fair }\end{array}$ & 15 & 21 & 36 & 36.7 & 4 & 18.2 & 39 & 19 & 58 & 59.2 \\
\hline 8 & $\begin{array}{c}\text { If I fail in CA I know that I will get another chance to } \\
\text { improve it }\end{array}$ & 11 & 23 & 34 & 34.7 & 2 & 9.1 & 41 & 21 & 62 & 63.2 \\
\hline 9 & $\begin{array}{c}\text { CA has given me the opportunities to establish my own } \\
\text { study programs }\end{array}$ & 25 & 41 & 66 & 67.3 & 1 & 4.5 & 12 & 19 & 31 & 31.6 \\
\hline 10 & $\begin{array}{l}\text { CA has given me the opportunities to consider my } \\
\text { strong and weak sides in my language learning }\end{array}$ & 13 & 23 & 36 & 36.7 & 4 & 18.2 & 36 & 22 & 58 & 59.2 \\
\hline 11 & $\begin{array}{l}\text { CA improved my training in English better than the } \\
\text { conventional ones }\end{array}$ & 27 & 36 & 53 & 54.1 & 2 & \begin{tabular}{|l|}
9.1 \\
\end{tabular} & 23 & 20 & 43 & \begin{tabular}{|l|}
43.8 \\
\end{tabular} \\
\hline 12 & $\begin{array}{c}\text { CA makes me be an independent learner more than the } \\
\text { conventional assessment }\end{array}$ & 11 & 24 & 35 & 35.7 & 1 & 4.5 & 27 & 35 & 62 & \begin{tabular}{|l|l|}
63.3 \\
\end{tabular} \\
\hline 13 & $\begin{array}{l}\text { CA has given me the chance to work on tasks } \\
\text { cooperatively with my peers }\end{array}$ & 26 & 28 & 54 & 55.1 & 1 & 4.5 & 31 & 12 & 43 & 43.8 \\
\hline 14 & $\begin{array}{c}\text { I do not worry when my teachers give me tasks in CA } \\
\text { as I do in conventional assessment }\end{array}$ & 13 & 24 & 37 & 37.8 & 2 & \begin{tabular}{|l|}
9.1 \\
\end{tabular} & 37 & 23 & 60 & \begin{tabular}{|l|}
61.2 \\
\end{tabular} \\
\hline 15 & $\begin{array}{l}\text { Individual student's accountability in CA does not } \\
\text { exist; students depend on the work of others }\end{array}$ & 29 & 34 & 63 & 64.3 & 1 & 1 & 22 & 12 & 34 & \begin{tabular}{|l|l}
34.7 \\
\end{tabular} \\
\hline
\end{tabular}

As can be seen from Table 4, about two-thirds (70.4\%) of the students reported that they did not make self-assessment on their own work in CA. More than half of them $(57.1 \%)$ also indicated that they did not get feedback on their progress from their teachers and peers. In item 3, 77.27\% of the respondents replied that their teachers' assessment focused on the products rather than on the process. The students' response to item 3 is supported by their responses to item 4. More than seventy five of them (76.5\%) agreed that their teachers used CA not to see the students' language learning progress, but to label or grade them. Moreover, $58.2 \%$ of the respondents reported that CA did not help them in understanding what they should improve next.

According to Plessis et al (2003), teachers should involve students in assessing their own and others' work so that they become responsible for their own learning. In addition to this, teachers are expected to monitor each student's participation in group project in order to avoid students' dependability on others' work.

Table 5: Review of Teachers' Responses to Their view of CA

\begin{tabular}{|c|c|c|c|c|c|c|c|c|c|c|c|}
\hline \multirow{3}{*}{$\begin{array}{l}\text { Ser } \\
\text { No }\end{array}$} & \multirow[t]{3}{*}{ Questionnaire Items } & \multicolumn{2}{|c|}{ Agreement } & \multirow{3}{*}{$\begin{array}{c}\text { Total } \\
\mathrm{f}\end{array}$} & \multicolumn{3}{|c|}{ Uncertain } & \multicolumn{2}{|c|}{ Disagreement } & \multicolumn{2}{|c|}{ Total } \\
\hline & & $\begin{array}{l}\text { Strongly } \\
\text { Agree }\end{array}$ & Agree & & \multirow[t]{2}{*}{$\%$} & \multirow[t]{2}{*}{$\mathrm{f}$} & \multirow[t]{2}{*}{$\%$} & Disagree & $\begin{array}{l}\text { Strongly } \\
\text { Disagree }\end{array}$ & $\mathrm{f}$ & $\%$ \\
\hline & & $\mathrm{f}$ & $\mathrm{F}$ & & & & & $\mathrm{f}$ & $\mathrm{F}$ & & \\
\hline 1 & Giving feedback is an integral part of continuous assessment & 15 & 7 & 22 & 100 & - & - & - & - & - & - \\
\hline 2 & $\begin{array}{l}\text { Feedback in CA focuses on what students' can't do rather than } \\
\text { what hey can do }\end{array}$ & 2 & 18 & 20 & 81 & & & 2 & - & & 19 \\
\hline 3 & $\begin{array}{l}\text { Feedback should be given by the teacher; not by the students in } \\
\text { continuous assessments }\end{array}$ & 12 & 5 & 17 & 77.27 & - & - & 1 & 4 & $5 \mathrm{~s}$ & 11.3 \\
\hline 4 & $\begin{array}{l}\text { Feedback in CA mainly consists of reporting right and wrong } \\
\text { answers to the learners }\end{array}$ & 4 & 7 & 11 & 50 & 3 & 13.6 & 4 & 1 & 5 & 22.7 \\
\hline 5 & $\begin{array}{l}\text { The emphasis of continuous assessment is more on products } \\
\text { than the process }\end{array}$ & 3 & 10 & 13 & 59.1 & 1 & 4.5 & 4 & 1 & 5 & 22.7 \\
\hline 6 & $\begin{array}{c}\text { I feel that continuous assessment helps to see students strengths } \\
\text { and weaknesses better than conventional assessment }\end{array}$ & 12 & 4 & 16 & 72.7 & 3 & 13.6 & 1 & - & 1 & 4.5 \\
\hline 7 & I feel that continuous assessment is used just to label students & 3 & 10 & 13 & 59.1 & 4 & 18.2 & - & 3 & 3 & 13.6 \\
\hline 8 & $\begin{array}{c}\text { I know that continuous assessment motivates students to be } \\
\text { engaged in their learning }\end{array}$ & 12 & 5 & 17 & 77.3 & 2 & 9.1 & 1 & - & 1 & 4.5 \\
\hline 9 & $\begin{array}{c}\text { I believe that continuous assessment addresses students' interests } \\
\text { and needs more than the conventional assessment }\end{array}$ & 5 & 13 & 18 & 81.8 & 2 & 9.1 & 2 & - & 2 & 9.1 \\
\hline
\end{tabular}




\section{International Journal of Science and Research (IJSR) \\ ISSN (Online): 2319-7064}

Index Copernicus Value (2015): 78.96 | Impact Factor (2015): 6.391

\begin{tabular}{|c|c|c|c|c|c|c|c|c|c|c|}
\hline 10 & $\begin{array}{c}\text { CA prevents teachers from being the central authority in decision } \\
\text { making }\end{array}$ & 3 & 10 & 13 & 59.1 & 4 & 18.2 & 2 & 1 & 3 \\
\hline 11 & $\begin{array}{c}\text { It is the teacher who is responsible for deciding the marking } \\
\text { criteria; not the students in continuous assessment }\end{array}$ & 1 & 14 & 15 & 68.2 & 3 & 13.6 & 1 & 1 & 2 \\
\hline 12 & $\begin{array}{c}\text { It is definitely possible for students to make an assessment of } \\
\text { their own progress in continuous assessment }\end{array}$ & 8 & 2 & 10 & 45.5 & 1 & 4.5 & 9 & 2 & 11 \\
\hline 13 & $\begin{array}{c}\text { I feel that there is a lack of individual accountability in } \\
\text { continuous assessment: students depend on the work of others }\end{array}$ & 6 & 10 & 16 & 72.7 & 1 & 4.5 & 3 & - & 3 \\
\hline 14 & $\begin{array}{c}\text { I know that attendance and punctuality are given marks as part of } \\
\text { continuous assessment }\end{array}$ & 4 & 11 & 15 & 68.2 & - & - & 3 & 2 & 5 \\
\hline 15 & $\begin{array}{c}\text { Continuous assessment does not differentiate students according } \\
\text { to their language ability }\end{array}$ & 3 & 4 & 7 & 31.8 & 2 & 9.1 & 9 & 4 & 13 \\
\hline
\end{tabular}

As can be seen from Table 5, all teachers reported that continuous assessment is an integral component of the teaching learning process (item 1 ). In item $2,81 \%$ of them said that feedback should focus on what students cannot do. On the other hand, $77.27 \%$ of the teachers indicated that students should be involved in giving feedback (item 3), but in item 4 more than half of the respondents $(50 \%)$ claimed that feedback does not only consist of right and wrong answers but also it contains the comments that indicate what was right and wrong. In item 5, 59\% of the teachers consented that the emphasis of continuous assessment should mainly be on the product. Most of the respondents (72.7\%) reported that continuous assessment helps to find out the strengths and weaknesses of students more than conventional assessment (item 6). However, 59.1\% of the teachers agreed that continuous assessment is used to label students (item 7).

On the other hand, $72.73 \%$ of the EFL teachers agreed that CA differentiates students according to their language ability. However, Plessis et al (2003) state that teachers need to use the different CA devices, such as observation, reflective journal, projects effectively in order to find out the language abilities of students and differentiate them 4.6 Teachers' Continuous Assessment Practices and Challenges: Qualitative Data Literature on assessment has a concern on quality of the existing practices of colleges, since there is a shift from summative to formative assessment. It would seem timely to identify the major problems that hinder the effectiveness of the continuous assessment. The major problems associated with continuous assessment can be summarized from open-ended questionnaire, interview and observation as follows.

\subsubsection{Response to Open ended Questionnaire}

The questions asked to the instructors include the possible factors they think can affect the implementation of CA to English Language, CA methods they apply, purposes of using FA results and typical tasks they give to the studentteachers to carry outthe process. Workload and class size cases have beenmentioned as major challenges that hinder the effective implementation of continuous assessment. The additional factors pointed out by the instructors include lack of proper feedback provision and its poor quality and emphasis still given to SA in the college. Finally, poorpreparation of modules, lack of CA activities, and lack of commitment, motivation and interest from the instructors' side were the further factors which need advance research.

\subsubsection{Interview}

To collect data regarding whether instructors CA implementation was effective or not and to explore what were the setbacks of this implementation; four deans ( 2 academic vice deans and 2 deans)- educators were interviewed. The data from four of the dean-educators was orally interviewed. Results of Interview with college deans and instructors in response to the mechanisms which the colleges uses checking whether instructors implement assessment continuously. The deans responded that they did not have any ways of checking and they had not attempted to do so. The deans' failure to check and balance the continuous assessment process results in poor student performance as a whole.

\subsection{Observation}

The lesson was almost instructor centered where the students passively learned. This indicates that there was rare chance of CA feedback exchange between the learners and the teacher and among the learners as the teacher wrote just the numerical value the learners scored. Furthermore, even the quantitative feedback provided was not immediate and hence contributed little to indicating learning progress. There was no chance of using peer and self-assessment techniques to reduce the load gaps.

\subsection{Document analysis}

Document analysis was performed to check up the rate of English teachers' continuous assessment from the two colleges. To see the trends of teachers' continuous assessment attrition, the documents from the Academics dean and department heads were consulted. For this purpose documents from 2010-2015 were analyzed. Both colleges used similar CA techniques. As the researcher assured that those techniques were group work, individual work, quiz, class participation and attendance, mid exam and final exam. Generally from the triangulation of the data gathering instruments the following problems were deduce:-

The common problems that most of the instructors and other stakeholders reported were large classroom size, time constraint, high work load, students' lack of awareness about CA, students' background, teachers' lack of adequate knowledge and skills of CA, and teachers' lack of experience in using it. 


\section{International Journal of Science and Research (IJSR)}

ISSN (Online): 2319-7064

Index Copernicus Value (2015): 78.96 | Impact Factor (2015): 6.391

\section{Summary, Conclusion and Recommendation}

\subsection{Summary}

The main objectives of this study were to examine the existing hindrances of implementing continuous assessment to identify hindrances released to the implementation of CA and finally to recommend alternative solutions for the improvement of the exiting challenges in implementing continuous assessment of high school.

According to Brown (2004), a major paradigm shift away from an emphasis on exam-oriented assessment to the ongoing $\mathrm{CA}$ is vital towards improving learning and planning for better teaching. He also says that although both FA and SA are possibly applicable to improve all aspects of language assessment, the former is very essential in particular way to assess different skills. From this standpoint, the research showed that there is a partial practice of the CA activities in the college to assess students' different skills work. This research was, therefore, conducted with the target of assessing the implementation of $\mathrm{CA}$ in the EFL classes in the college. The study provides approaching into the nature of assessment practices in the college.

\subsection{Conclusion}

From the findings of this study, the following conclusions can be drown Among the many hindrances that affect the implementation of continuous assessment, are found to be practical factors such as pupils' negative attitude towards EFL, large class size, shortage of time, in adequacy of materials and teachers' inadequate knowledge due to lack of on job-training. A substantial number of EFL teachers in the sample schools considered continuous assessment as simply giving series of tests for students. It was also found out that physical education teachers do not use various assessment methods to check the students' mastery of the desired knowledge, skills and attitudes. On the other hand, assessment focuses on grading.

\subsection{Recommendations}

Based on questionnaire, interviews, open-ended questions, classroom observation and the reviews of literature, the following informative suggestions have been recommended:

\section{The instructors should:}

- Describe student-teachers to variety of diagnostic informal or formal assessment activities to see where they are with reference to some decided standards.

- organize checklists to recordstudents' learning progress and discuss with them.

- Plan standards and inform them in advance to the learners to avoid anxiety exercise self and peer assessment techniques regularly to reduce assessment loads

- Assist peers to present their written work in different times or periods.

\section{The college regional education bureau should:}

Reduce some of assessment problems such as large class size and heavy teaching loads through revising the number of students an instructor-educator should assess.
Make the grading scale of students' performance in agreement with the assessment policy proposed by TESO (AED, 2006), that is, criteria-reference framework should be used consistently.

\section{Student-teachers should:}

Be actively engaged in assessing themselves and their peers through some checklist.

Know that self and peer assessments do not directly affect the final grade but help them reduce assessment loads, develop their confidence as well.

\section{References}

[1] Academy for Education Development (2006).A concise manual fordeveloping and implementingcontinuous assessment in teachereducation institutions and primaryschool of Ethiopia.Addis Ababa: Alem printing press

[2] Brown, G., Bull, J. and Pendlebury, M. (1997). Assessing Student Learning in Higher Education.London: Routledge.

[3] Brown,S.(1996).Assessment in the Classroom. London: Rout ledge.

[4] Brooks, V. (2002).Assessment in Secondary School: Recording, Reporting and Accountability. Buckingham: Open University Press.

[5] Burke, K. (1999). How to Assess Authentic Learning ( $3^{r d}$ ed.). Boston: Skylight Training and Publishing.

[6] Burke, K., Fogarty, R. J. \&Belgread, S. (1999). The Portfolio Connection $\left(2^{\text {nd }} e d\right.$.). Boston: Sky Light Training and Publishing.

[7] Cone, J. D. and Foster, S.L. (1991).Training in Measurement: Always the Bribesmaid. American Psychologist, 46/6, PP 633-654.71

[8] Heaton, J. B. (1988). Writing English Language Tests. London: Longman Group Limited

[9] Nitko, A. J. (2004). Educational Assessment of Students $\left(4^{\text {th }}\right.$ ed.).Upper Saddle River, NJ: Prentice 